may be at least 150 species in total. Thus, the synonymy rate here is most probably below $5 \%$.

These examples show that different groups may have widely different synonymy rates. Long lists of synonyms may be expected for large, easily collected organisms with extensive geographical ranges and conspicuous individual variation. Conversely, hard to find, minute species with restricted ranges and uninteresting external appearance are likely to have none or few. Synonymy rates are affected by changing species concepts and improved analytical tools, rather than by continuous, predictable error of taxonomists.

Estimates of global biodiversity should therefore not rely on the number of described species, as this parameter is too uncertain to provide any consistent estimate. Clearly, there is a need for more updated, robust taxonomic revisions, but taxonomy is a scientific discipline relevant on its own, able to contribute significantly to the preservation of biodiversity ${ }^{3,9}$. Because the true extent of diversity in these three groups of molluscs has been unrecognized until now, these animals have been largely ignored by conservationists. It is sad indeed that many of these species, often still undescribed, are threatened or already extinct.

\section{Cristian R. Altaba}

Institut d'Estudis Avancats de les

IIIes Balears (CSIC-UIB),

Ctra. de Valldemossa, $\mathrm{Km} \mathrm{7.5,}$

07071 Palma de Mallorca,

Illes Balears, Spain

\title{
Solvent-forming genes in clostridia
}

SIR - The Weizmann process ${ }^{1}$, in which the bacterium Clostridium acetobutylicum converts corn starch into acetone and butanol, was used during the First World War to produce the acetone needed for smokeless gunpowder. The loss of the Weizmann strain's capacity to produce solvents after repeated subculture (degeneration $)^{2}$ is still not understood from the molecular viewpoint ${ }^{3}$. We show here that the solventogenic genes ${ }^{4,5}$ encoding the enzymes required for acetone and butanol formation are carried on a 210-kilobase (kb) plasmid (pWEIZ), and that three degenerate strains lack both these solventogenic genes and pWEIZ.

To investigate the molecular basis of degeneration, we isolated three spontaneous degenerate mutants (WDS1, 2 and 3) of C. acetobutylicum ATCC 4259 (the Weizmann strain used in warfare ${ }^{6}$ ) through serial subculturing. None of the mutants produced any detectable amounts of butanol or acetone, nor did they sporulate. DNA from the wild-type and mutant strains was prepared in agarose plugs and analysed by pulsed-field gel electrophoresis (PFGE).
Below a band of sheared chromosomal DNA in our gels, we always observed an extra band at $210 \mathrm{~kb}$ in the wild-type strain which was absent from all the degenerate mutants (see figure). DNA from the Weizmann strain digested by SmaI, ApaI or SstII (see figure for the SmaI digest only) has a considerably higher- intensity $210-\mathrm{kb}$ band than has the uncut DNA, whereas there is no $210-\mathrm{kb}$ band for WDS1 DNA digested by the same enzymes. Because circular DNA cannot enter the gel in $\mathrm{PFGE}^{7}$, our data demonstrate: first, that $C$. acetobutylicum Weizmann contains a $210-\mathrm{kb}$ plasmid (linearized by ApaI, SmaI and SstII); second, that a small portion of it is linear in uncut DNA preparation; and third, that it is lost in the degenerate strains.

The genes encoding the enzymes required for the last steps of acetone and butanol production are clustered in the sol operon locus ${ }^{4,5}$. To check whether these genes are carried on the plasmid, we used as a probe $c t f A$ and $c t f B$ genes (from $C$. acetobutylicum Weizmann), amplified by the polymerase chain reaction (PCR), encoding the two subunits of the

Ethidium bromide-stained unrestricted (lanes 1, 2) and Smal-digested (lanes 3, 4) DNA from C. acetobutylicum Weizmann (odd lane numbers) and WDS1 (even lane numbers) after separation by PFGE. The $1 \%$ agarose gel was run in $\times 0.5$ Tris-borate EDTA buffer for $18 \mathrm{~h}$ at $200 \mathrm{~V}\left(6 \mathrm{~V} \mathrm{~cm}^{-1}\right)$ using a linear ramp of pulse time from 10 to $50 \mathrm{~s}$. Autoradiogram obtained, after hybridization with the PCR-amplified $c t f A$ and $B$ genes used as a probe, for unrestricted (lanes 5,6 ) and Smal-digested (lanes 7, 8) DNA from C. acetobutylicum Weizmann and WDS1.

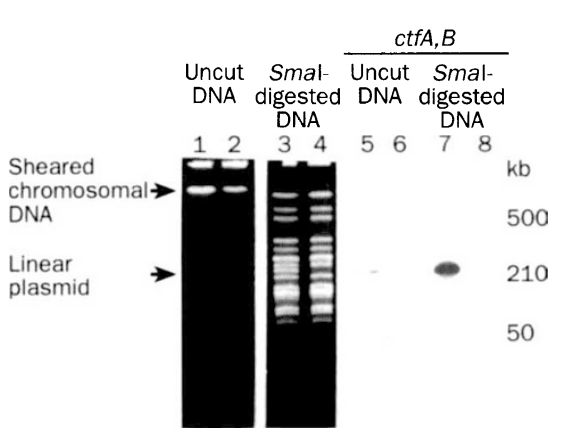
DNA was blotted on Hybond $\mathrm{N}^{+}$(Amer-

sham). The probe was labelled by random-priming with $\left[\alpha^{32} \mathrm{P}\right]-\mathrm{dATP}$ and purified on a Microspin S200 (Pharmacia) column. Hybridization was performed at $65^{\circ} \mathrm{C}$ in $5 \times$ SSC, $5 \times$ Denhardt, $0.5 \%$ SDS. Blots were washed at room temperature twice for $10 \mathrm{~min}$ in $2 \times$ SSC $0.1 \%$ SDS and twice for $30 \mathrm{~min}$ in $0.1 \times$ SSC $0.1 \%$ SDS.

acetoacetyl-CoA: acetate/butyrate:CoAtransferase, one of the two enzymes involved in the final steps of acetone formation. We obtained a hybridization signal with the $210-\mathrm{kb}$ linearized plasmid forms of $C$. acetobutylicum Weizmann, but no signal with WDS1 (see figure), indicating that the plasmid carries the sol operon locus. This plasmid was named pWEIZ.

Our finding raises an obvious question: what is the natural selective pressure for the maintenance of pWEIZ? The answer is probably linked to the fact that all the C. acetobutylicum strains that have lost pWEIZ also do not sporulate. It is tempting to speculate that an essential gene(s) needed for sporulation might be carried by the plasmid.

\section{Emmanuel Cornillot \\ Philippe Soucaille}

INSA, Centre de Bioingénierie

Gilbert Durand,

Complexe Scientifique de Rangueil,

F-31077 Toulouse Cédex, France

1. Weizmann, C. UK Patent 4845 (1915).

2. Bahl, H., Andersh, W., Braun, K. \& Gottschalk, G. Eur. J. appl. Microbiol. Biotechnol. 15, 201-205 (1982).

3. Woods, D. R. Trends Biotechnol. 13, 259-264 (1995).

4. Petersen, D. J., Cary, J. W., Vanderleyden, J. \& Bennett, G. N. Gene 123, 93-97 (1993).

5. Fischer, R. J., Helms, J. \& Dürre, P. J. Bact. 175, 6959-6969 (1993).

6. Keis, S., Bennett, C. F., Ward, V. K. \& Jones, D. T. Int. J. syst. Bact. 45, 693-705 (1995).

7. Beverley, S. M. Nucleic Acids Res. 16, 925-939 (1995).

\section{Mammal bones in Dominican amber}

SIR - When and how did land vertebrates colonize the Greater Antilles, West Indies, during the Cenozoic? Were colonization events sporadic and fortuitous, or were they tightly clustered in time, suggesting the operation of a common cause (see ref. 1)? Fossils should help with these enquiries, but discoveries in conventional palaeontological contexts on these islands are exceedingly rare ${ }^{2}$.

To a certain extent, this deficiency is made up by finds in Dominican amber, specimens of which occasionally contain small lizards and frogs. However, evidence for the presence of larger vertebrates, especially birds and mammals, has so far been limited to isolated (and rather undiagnostic) feathers and hair strands. We now report the discovery of the first mammal bones in Dominican amber ( $A, B$ in the figure), the identification of which provides additional evidence for the view $^{3}$ that most mammalian colonizations were clustered early in the Tertiary.

The amber piece, containing six vertebrae and portions of several ribs in partial articulation, is reliably reported to have been collected from the La Toca group of amber mines in the La Cumbre region of the northern Dominican Republic. It lacks features indicative of forgery ${ }^{4}$, and we conclude that it is authentic. Recent re-analy- 